\title{
Antioxidant and Anti-Inflammatory Activities of Berberine in the Treatment of Diabetes Mellitus
}

\author{
Zheng Li, ${ }^{1}$ Ya-Na Geng, ${ }^{1}$ Jian-Dong Jiang, ${ }^{2}$ and Wei-Jia Kong ${ }^{1}$ \\ ${ }^{1}$ Department of Pharmacology, Institute of Medicinal Biotechnology, Chinese Academy of Medical Sciences \\ and Peking Union Medical College, Beijing 100050, China \\ ${ }^{2}$ State Key Laboratory of Bioactive Natural Products and Function, Institute of Materia Medica, Chinese Academy of Medical Sciences \\ and Peking Union Medical College, Beijing 100050, China
}

Correspondence should be addressed to Jian-Dong Jiang; jian-dong-jiang@sohu.com and Wei-Jia Kong; wjkong894@163.com

Received 24 November 2013; Revised 30 December 2013; Accepted 2 January 2014; Published 11 February 2014

Academic Editor: Yao Tong

Copyright (c) 2014 Zheng Li et al. This is an open access article distributed under the Creative Commons Attribution License, which permits unrestricted use, distribution, and reproduction in any medium, provided the original work is properly cited.

\begin{abstract}
Oxidative stress and inflammation are proved to be critical for the pathogenesis of diabetes mellitus. Berberine (BBR) is a natural compound isolated from plants such as Coptis chinensis and Hydrastis canadensis and with multiple pharmacological activities. Recent studies showed that BBR had antioxidant and anti-inflammatory activities, which contributed in part to its efficacy against diabetes mellitus. In this review, we summarized the antioxidant and anti-inflammatory activities of BBR as well as their molecular basis. The antioxidant and anti-inflammatory activities of BBR were noted with changes in oxidative stress markers, antioxidant enzymes, and proinflammatory cytokines after BBR administration in diabetic animals. BBR inhibited oxidative stress and inflammation in a variety of tissues including liver, adipose tissue, kidney and pancreas. Mechanisms of the antioxidant and anti-inflammatory activities of BBR were complex, which involved multiple cellular kinases and signaling pathways, such as AMPactivated protein kinase (AMPK), mitogen-activated protein kinases (MAPKs), nuclear factor erythroid-2-related factor-2 (Nrf2) pathway, and nuclear factor $-\kappa \mathrm{B}(\mathrm{NF}-\kappa \mathrm{B})$ pathway. Detailed mechanisms and pathways for the antioxidant and anti-inflammatory activities of BBR still need further investigation. Clarification of these issues could help to understand the pharmacology of BBR in the treatment of diabetes mellitus and promote the development of antidiabetic natural products.
\end{abstract}

\section{Introduction}

For decades, diabetes mellitus especially type 2 diabetes mellitus (T2DM) has become a public health problem and threatened the people worldwide, not only in western countries, but also in the developing world like China. The pathogenesis and pathophysiological processes of T2DM are extreme complex and remain to be controversial. However, a growing number of evidences showed that oxidative stress and inflammation might play important roles in the development of T2DM $[1,2]$.

In metabolic disorders, oxidative stress could be typically induced by excessive nutritional factors like glucose and free fatty acids (FFA) $[3,4]$. Oxidative stress could induce or deteriorate insulin resistance and diabetes through multiple mechanisms. In the process of oxidative stress, excessive reactive oxygen species (ROS) were produced, mainly by mitochondria [5]. ROS include superoxide anion $\left(\mathrm{O}_{2}{ }^{-\bullet}\right)$, hydroxyl radical $\left(\mathrm{OH}^{*}\right)$, hydrogen peroxide $\left(\mathrm{H}_{2} \mathrm{O}_{2}\right)$ [6]. They could cause damage and apoptosis of pancreatic islet $\beta$-cells and reduction of insulin secretion [7]. ROS could activate cellular signaling pathways like $c$-jun $\mathrm{N}$-terminal kinase (JNK), protein kinase $\mathrm{C}(\mathrm{PKC})$, and nuclear factor- $\kappa \mathrm{B}$ (NF$\kappa \mathrm{B})$ and then interfere with the insulin signaling pathway and cause insulin resistance [8-10]. In addition, oxidative stress also contributes to the development of chronic complications of diabetes, such as diabetic nephropathy, retinopathy, and neuropathy [6].

Recently, results from laboratory studies as well as clinical investigations have proved that diabetes is in fact an inflammatory disease $[2,11]$. The importance of inflammation in insulin resistance, diabetes and complications has been critically reviewed [12-16], concerning relevant proinflammatory cytokines as well as cellular signaling pathways. 
In the pathogenesis of diabetes mellitus, proinflammatory cytokines such as tumor necrosis factor- $\alpha$ (TNF- $\alpha$ ) and interleukin-6 (IL-6) could be produced by immunocytes (like macrophages) and adipocytes [12-14]. TNF- $\alpha$ and IL-6 were important mediators of insulin resistance, as they could induce serine phosphorylation of insulin receptor substrate (IRS) through activation of JNK or NF- $\kappa \mathrm{B}$ pathway $[14,16]$. Furthermore, overproduction of TNF- $\alpha$ and IL- 6 in pancreas could cause islet dysfunction and accelerate the progression of diabetes [13].

There are a number of medications available in clinic to treat T2DM. In addition to chemical drugs, a number of natural products or traditional Chinese medicine (TCM) formulas were reported to have antidiabetic or insulinsensitizing activities, and some of them have been used in clinic with a long history $[11,17,18]$. Berberine $(\mathrm{BBR})$ is a natural compound isolated from plants such as Coptis chinensis and Hydrastis canadensis and with multiple pharmacological activities [19]. The emerging role of BBR in modifying sugar and lipid metabolism has been verified in a large amount of experimental and clinical studies [20-23].

In general, BBR was safe and effective in the treatment of patients with T2DM [19-21, 23, 24]. The glucose-lowering efficacy of BBR was close to those of metformin and rosiglitazone $[23,24]$. Notably, due to the low toxicity, BBR could be used in diabetic patients with chronic hepatitis [24]. Beneficial effects of BBR were also observed in combating diabetic complications. Diabetes related endothelial dysfunction, nephropathy, and neuropathy could be relieved after BBR administration [21].

Mechanisms of BBR in restoring insulin sensitivity and lowering blood glucose included inhibition of mitochondrial function and activation of AMP-activated protein kinase $(\mathrm{AMPK})$, regulation of islet function, modulation of gut microenvironment, and upregulation of insulin receptor expression [20-22, 24-26]. Recent studies showed that BBR had beneficial effects on cellular oxidative stress and inflammation, which could also play important roles in its activity against diabetes mellitus. In this paper, we reviewed the antioxidant and anti-inflammatory activities as well as their molecular basis of BBR in treating diabetes mellitus and insulin resistance.

\section{Antioxidant Activity and Mechanisms of BBR in Treating Diabetes Mellitus}

2.1. BBR Reduced Oxidative Stress in Diabetes Mellitus. The inhibitory effect of BBR on oxidative stress was observed both in cells cultured with high glucose-containing media [38] and in a series of diabetic animal models (Table 1) [27-30, 3237]. The antioxidant activity of BBR was revealed by changes of oxidative stress markers as well as antioxidant enzymes. Oxidative stress markers include malondialdehyde (MDA), a product of lipid peroxidation which increases during oxidative stress [39], as well as glutathione (GSH), which often declines during oxidative stress [40]. GSH is an antioxidant itself and is a substrate of glutathione peroxidase (GSH-Px) in the clearance of peroxides [40]. In addition to GSH-Px, another well-known antioxidant enzyme, superoxide dismutase (SOD), is also involved to evaluate the inhibitory effect of $\mathrm{BBR}$ on oxidative stress. Antioxidant enzyme is a part of the antioxidant defense mechanisms, which helps to maintain the balance of redox in organisms and could be damaged in the pathogenesis of diabetes mellitus [41].

As summarized in Table 1, the majority of reports [27-30, 32-37] supported the antioxidant activity of BBR in diabetic animal models, which were induced by streptozotocin (STZ) or alloxan injection with or without high fat diet (HFD) feeding. The relief of oxidative stress by BBR was noted by changes of oxidative stress markers as well as antioxidant enzymes. In general, BBR administration decreased MDA content and increased the contents of SOD, GSH and GSH$\mathrm{Px}$, which would help to scavenge excessive free radicals and overcome oxidative stress $[40,41]$. In only one of the reports [31], the effect of BBR on oxidative stress seemed not to be obvious. However, in this report [31], the contents of MDA and SOD of the diabetic animals did not have statistically significant difference as compared with those of the normal control animals, inconsistent with the results from other reports [27-30, 32-37]. In another report [30], BBR treatment greatly upregulated the mRNA level of SOD but decreased GSH and GSH-Px contents in diabetic mice. In this report [30], while SOD was observed to be reduced in diabetic mice, the amounts of GSH and GSH-Px were increased, probably due to the acute stage of experimental diabetes mellitus [52], which usually occurred within 3-4 weeks of STZ injection $[53,54]$. So, it seems that BBR could regulate the GSH/GSHPx antioxidant mechanism differentially at different stages of diabetes mellitus.

The antioxidant activity of BBR was associated with its inhibitory effect on the development of diabetes mellitus and insulin resistance induced by STZ/alloxan + HFD in animals [32-35]. Furthermore, BBR inhibited oxidative stress in a variety of tissues, such as the serum [27-29], liver [29, 30, 32], kidney [32, 33], pancreas [34], heart [35] and central nerve system $[36,37]$. The inhibitory effect of BBR on oxidative stress was associated with its activity against renal injury $[27,28,33]$, pancreatic islet dysfunction [34], and memory impairment [36] in diabetic animals.

2.2. Mechanisms and Pathways of BBR against Oxidative Stress. Molecular mechanisms of BBR in reducing oxidative stress seem to be related with multiple cellular pathways and need further investigation. The schematic illustration of the pathways from available data was presented in Figure 1.

It was reported that BBR scavenged superoxide free radicals directly in vitro in a system containing alkaline dimethyl sulfoxide (DMSO) [55]. The mRNA expression level of SOD could be upregulated by BBR in diabetic mice, and it played a role in BBR's activity against oxidative stress [30, 32]. Also, BBR was reported to increase the expression level of sirtuin 1 (SIRT1) [56], a deacetylase with multiple biological activities and antioxidant activity [57]. In oxidative stress, SIRT1 could induce deacetylation of the forkhead box $\mathrm{O}$ (FOXO) transcription factors and increased the transcription of their target genes, which included SOD [58]. It is possible 
TABLE 1: Effects of BBR on parameters of oxidative stress in animals with diabetes mellitus.

\begin{tabular}{|c|c|c|c|c|c|c|c|}
\hline \multirow{3}{*}{ References } & \multirow{3}{*}{ Diabetic animal model } & \multirow{3}{*}{ Administration of BBR } & \multirow{3}{*}{$\begin{array}{l}\text { Tissues } \\
\text { examined }\end{array}$} & \multicolumn{4}{|c|}{ Effects of BBR } \\
\hline & & & & \multicolumn{2}{|c|}{ Oxidative stress markers } & \multicolumn{2}{|c|}{ Antioxidant enzymes } \\
\hline & & & & MDA & GSH & SOD & GSH-Px \\
\hline$[27]$ & $\begin{array}{l}\text { Wistar rats, STZ } 60 \mathrm{mg} / \mathrm{kg} \text {, } \\
\text { single i.p. injection }\end{array}$ & $\begin{array}{l}200 \mathrm{mg} / \mathrm{kg} / \mathrm{d} \text {, p.o. for } 12 \\
\text { weeks }\end{array}$ & Serum & $\downarrow$ & ND & $\uparrow$ & ND \\
\hline$[28]$ & $\begin{array}{l}\text { SD rats, } S T Z 60 \mathrm{mg} / \mathrm{kg} \text {, single } \\
\text { tail vein injection }\end{array}$ & $\begin{array}{l}200 \mathrm{mg} / \mathrm{kg} / \mathrm{d} \text {, p.o. for } 12 \\
\text { weeks }\end{array}$ & Serum & $\downarrow$ & ND & $\uparrow$ & ND \\
\hline [29] & $\begin{array}{l}\text { Wistar rats, STZ } 35 \mathrm{mg} / \mathrm{kg} \text {, } \\
\text { single i.p. injection, HFD for } \\
14 \text { weeks after } 2 \text { weeks on } \\
\text { diabetes }\end{array}$ & $\begin{array}{l}75,150 \text {, and } \\
300 \mathrm{mg} / \mathrm{kg} / \mathrm{d} \text {, p.o. for } 16 \\
\text { weeks }\end{array}$ & $\begin{array}{l}\text { Serum and } \\
\quad \text { liver }\end{array}$ & $\downarrow$ & $\uparrow$ & $\uparrow$ & $\uparrow$ \\
\hline$[30]$ & $\begin{array}{l}\text { ddY mice, STZ } 100 \mathrm{mg} / \mathrm{kg} \text {, } \\
\text { single i.p. injection }\end{array}$ & $\begin{array}{l}200 \mathrm{mg} / \mathrm{kg} / \mathrm{d} \text {, p.o. for } 2 \\
\text { weeks }\end{array}$ & Liver & ND & $\downarrow$ & $\uparrow$ & $\downarrow$ \\
\hline$[31]$ & $\begin{array}{l}\text { SD rats, HFD for } 2 \text { weeks, } \\
\text { then } S T Z 35 \mathrm{mg} / \mathrm{kg} \text {, single i.p. } \\
\text { injection }\end{array}$ & $\begin{array}{l}\text { 50, } 100 \text {, and } 150 \mathrm{mg} / \mathrm{kg} / \mathrm{d} \text {, } \\
\text { p.o. for } 6 \text { weeks }\end{array}$ & Liver & - & - & - & ND \\
\hline$[32]$ & $\begin{array}{l}\text { ICR mice, nicotinamide } \\
1000 \mathrm{mg} / \mathrm{kg}+\mathrm{STZ} 100 \mathrm{mg} / \mathrm{kg} \text {, } \\
\text { single i.p. injection }\end{array}$ & $\begin{array}{l}100 \mathrm{mg} / \mathrm{kg} / \mathrm{d} \text {, p.o. for } 2 \\
\text { weeks }\end{array}$ & $\begin{array}{l}\text { Liver and } \\
\text { kidney }\end{array}$ & $\downarrow$ & $\mathrm{ND}$ & $\uparrow$ & ND \\
\hline$[33]$ & $\begin{array}{l}\text { SD rats, HFD for } 4 \text { weeks, } \\
\text { then STZ } 40 \mathrm{mg} / \mathrm{kg} \text {, single i.p. } \\
\text { injection, HFD for another } 8 \\
\text { weeks }\end{array}$ & $\begin{array}{l}100 \text { and } 200 \mathrm{mg} / \mathrm{kg} / \mathrm{d} \text {, } \\
\text { p.o. for } 8 \text { weeks }\end{array}$ & Kidney & $\downarrow$ & $\mathrm{ND}$ & $\uparrow$ & ND \\
\hline$[34]$ & $\begin{array}{l}\text { Wistar rats, STZ } 35 \mathrm{mg} / \mathrm{kg} \text {, } \\
\text { single i.p. injection, HFD for } \\
14 \text { weeks after } 2 \text { weeks on } \\
\text { diabetes }\end{array}$ & $\begin{array}{l}75,150 \text { and } 300 \mathrm{mg} / \mathrm{kg} / \mathrm{d} \text {, } \\
\text { p.o. for } 16 \text { weeks }\end{array}$ & Pancreas & $\downarrow$ & ND & $\uparrow$ & ND \\
\hline$[35]$ & $\begin{array}{l}\text { Wistar rats, alloxan } 55 \mathrm{mg} / \mathrm{kg} \text {, } \\
\text { single tail vein injection, then } \\
\text { on HFD }\end{array}$ & $\begin{array}{l}100 \text { and } 200 \mathrm{mg} / \mathrm{kg} / \mathrm{d} \text {, } \\
\text { p.o. for } 21 \text { days }\end{array}$ & Heart & $\downarrow$ & $\mathrm{ND}$ & $\uparrow$ & $\uparrow$ \\
\hline$[36]$ & $\begin{array}{l}\text { Wistar rats, STZ } 60 \mathrm{mg} / \mathrm{kg} \text {, } \\
\text { single i.p. injection }\end{array}$ & $\begin{array}{l}25,50 \text {, and } 100 \mathrm{mg} / \mathrm{kg} / \mathrm{d} \text {, } \\
\text { p.o. for } 30 \text { days }\end{array}$ & $\begin{array}{c}\text { Cortex and } \\
\text { hippocampus }\end{array}$ & $\downarrow$ & $\uparrow$ & $\mathrm{ND}$ & $\mathrm{ND}$ \\
\hline$[37]$ & $\begin{array}{l}\text { Wistar rats, STZ } 55 \mathrm{mg} / \mathrm{kg} \text {, } \\
\text { single i.p. injection }\end{array}$ & $\begin{array}{l}50 \text { and } 100 \mathrm{mg} / \mathrm{kg} / \mathrm{d} \text {, p.o. } \\
\text { for } 8 \text { weeks }\end{array}$ & Hippocampus & $\downarrow$ & $\mathrm{ND}$ & $\uparrow$ & $\mathrm{ND}$ \\
\hline
\end{tabular}

$\downarrow$ : decrease, $\uparrow:$ increase, ND: not determined, —: no effect; BBR: berberine, MDA: malondialdehyde, GSH: glutathione, SOD: superoxide dismutase, GSH-Px: glutathione peroxidase, STZ: streptozotocin, p.o.: per os/oral administration, i.p.: intraperitoneal, HFD: high fat diet.

that BBR increased SOD expression via the SIRT1/FOXO pathway, more experimental evidences are needed to support this point.

BBR could reduce oxidative stress by attenuating the expression level of nicotinamide adenine dinucleotide phosphate (NADPH) oxidase, which was a major source of ROS production in cells $[59,60]$. NADPH oxidase was able to be upregulated by high levels of fatty acids, glucose or advanced glycation end products (AGEs), resulting in overproduction of $\operatorname{ROS}[3,4,10]$. Among various NADPH oxidase isoforms, $\mathrm{BBR}$ was reported to suppress the overexpression of NADPH oxidase $2 / 4$ and decrease ROS production in macrophages and endothelial cells upon stimulation with inflammatory stimuli $[59,60]$.

Activation of NADPH oxidase is associated with the onset of diabetes, obesity and arthrosclerosis $[3,4,10]$. Now, NADPH oxidase is considered to be a potential target to treat diabetes and related complications [61, 62]. The inhibitory effect of BBR on NADPH oxidase and the subsequent ROS reduction could partially explain its beneficial effects on diabetic complications, such as nephropathy and endothelial dysfunction [21,60]. NADPH oxidase could be negatively regulated by AMP-activated protein kinase (AMPK) activation $[63,64]$, which was involved in the activities of BBR against diabetes mellitus [20]. However, whether BBR downregulated NADPH oxidase through AMPK activation, or not, remains unclear and need direct evidence.

AMPK seemed to play a pivotal role in mediating the antioxidant activity of BBR. Besides NADPH oxidase downregulation, AMPK activation was linked to the upregulation of SOD expression $[65,66]$, which was observed in BBR treated diabetic mice $[30,32]$. In addition, BBR could increase the expression of uncoupling protein 2 (UCP2) and inhibit oxidative stress in the artery of mice in an AMPK-dependent manner [67]. UCP2 is a member of the mitochondrial inner membrane proteins and was shown to be negatively related to ROS production and oxidative stress $[68,69]$. Conflicting results existed concerning the effect of BBR on the expression 


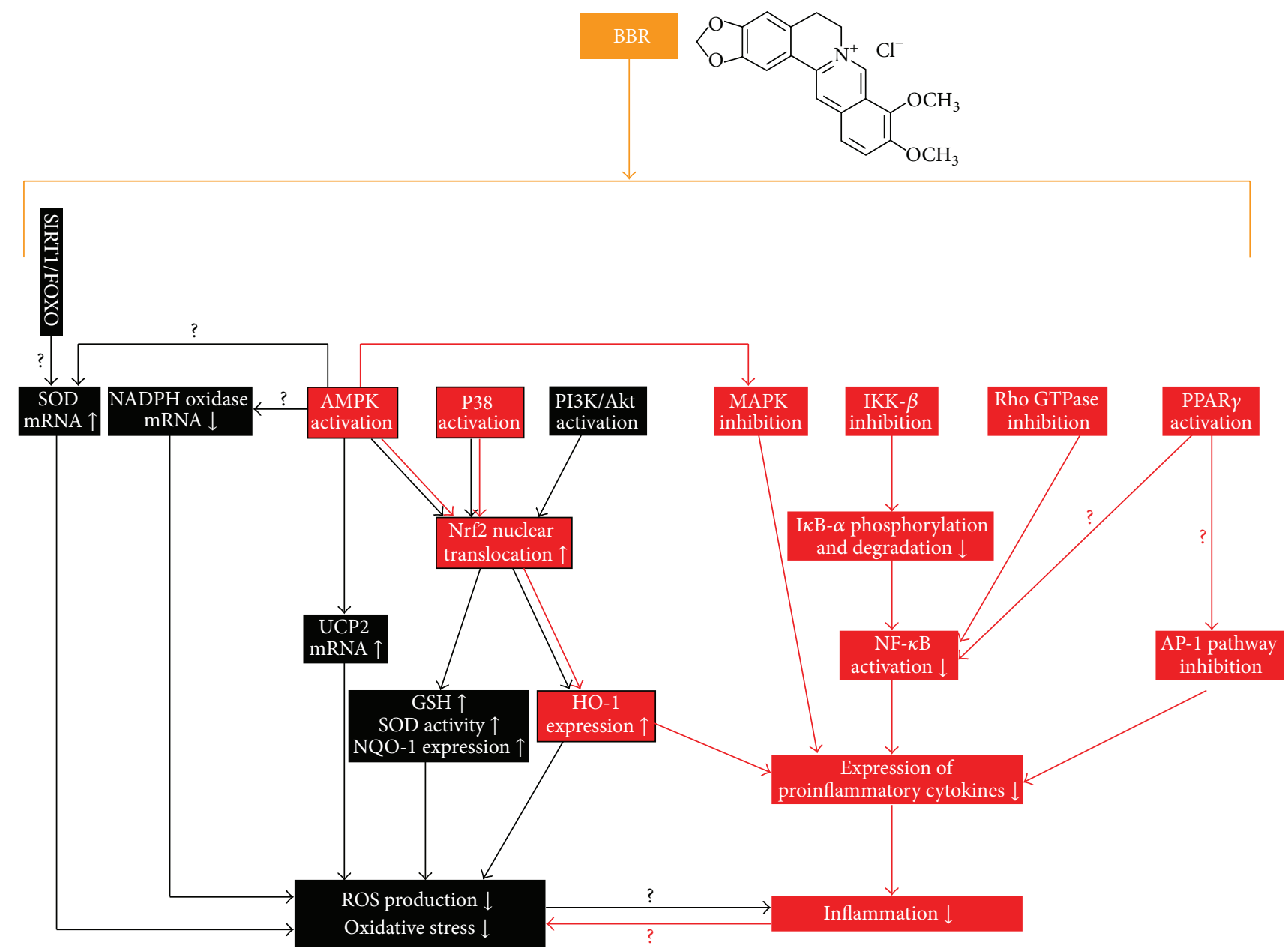

FIGURE 1: Schematic illustration of the molecular mechanisms and pathways of BBR in reducing oxidative stress and inflammation. (1) BBR could inhibit oxidative stress by upregulation of SOD, UCP2 and downregulation of NADPH oxidase expression, which was possible to be mediated by the SIRT1/FOXO or AMPK pathway. (2) BBR administration induced the activation of the Nrf2 pathway, which was crucial for the antioxidant and anti-inflammatory activities of BBR. The effect of BBR on Nrf2 relied on the activation of AMPK, PI3K/Akt, and P38 pathways. (3) BBR could suppress inflammation by blocking the MAPK pathways in an AMPK-dependent manner, inhibiting the classic NF- $\kappa$ B signaling pathway; inhibiting the Rho GTPase pathway, which was proved to play a role in NF- $\kappa$ B regulation, and attenuating the transcription activity of AP-1, which was possible to be mediated by PPAR $\gamma$ activation. The black lines/boxes and red lines/boxes indicate pathways and molecules involved in the antioxidant or anti-inflammatory activity of BBR, respectively. Red boxes with black frame indicate pathways and molecules responsible for both antioxidant and anti-inflammatory activities of BBR. The symbols of "?" indicate possible mechanisms and pathways that need to be further verified. There was a vicious cycle between oxidative stress and inflammation, which was possibly able to be terminated by BBR administration.

of UCP2. For example, in another report [70], BBR decreased the expression level of UCP2 in the liver in a rat model of nonalcoholic fatty liver disease (NAFLD) and reduced hepatic steatosis. Whether or not BBR regulates UCP2 in a tissue-specific manner is unknown and needs more study.

The relationship between UCP2 and diabetes mellitus was complex. On the one hand, upregulation of UCP2 in adipose tissue or kidney could reduce ROS production and relieve diabetes or relevant complication; but on the other hand, increased UCP 2 in islet $\beta$-cells was related to reduction of insulin secretion [71]. How UCP2 is regulated by BBR in $\beta$ cells is unknown and needs investigation.

Recent studies revealed that BBR suppressed oxidative stress through induction of the nuclear factor erythroid2-related factor-2 (Nrf2) pathway [72-75]. Nrf2 was an antioxidant transcription factor mediating the expression of antioxidant enzymes like NADPH quinine oxidoreductase1 (NQO-1) and heme oxygenase-1 (HO-1) [76]; it had a wide range of activities in regulating redox state and energy metabolism in cells [76]. Now, Nrf2 is recognized as an important mediator of BBR in reducing oxidative stress, as blocking Nrf2 abolishes the antioxidant activity of BBR in macrophages and nerve cells [72-75]. The activity of BBR on Nrf2 relied on the activation of several cellular signaling pathways including the AMPK pathway, phosphatidylinositol 3kinase (PI3K)/Akt pathway, and the P38 pathway (Figure 1), as blocking these pathways could diminish the stimulating effect of BBR on Nrf2 [72-75]. BBR activated these pathways, and then induced nuclear translocation of $\mathrm{Nrf} 2$ which could activate the expression of antioxidant enzymes, increase SOD 
TABLE 2: Effects of BBR on inflammatory cytokines and inflammation in cultured cells or animals with diabetes mellitus or insulin resistance.

\begin{tabular}{|c|c|c|c|c|}
\hline References & Cell type, animal model & Administration of BBR & Samples examined & Effects of BBR \\
\hline$[42]$ & 3T3-L1 adipocytes & $10 \mu \mathrm{M}$ for 18 hours & 3T3-L1 adipocytes & $\begin{array}{l}\downarrow: \text { TNF- } \alpha \text {, IL-6, CRP, and } \\
\text { HP mRNAs }\end{array}$ \\
\hline$[43]$ & $\begin{array}{l}\text { HepG2 cells, palmitate } \\
\text { induced insulin resistance }\end{array}$ & $0.1-10 \mu \mathrm{M}$ for 24 hours & Culture media & $\downarrow:$ TNF- $\alpha$, IL-6 \\
\hline$[44]$ & $\begin{array}{l}\text { RAW } 264.7 \text { macrophages } \\
\text { treated with LPS }\end{array}$ & $\begin{array}{l}5 \mu \mathrm{M} \text { pretreated for } 2 \text { hours } \\
\text { before LPS treatment for } 6 \\
\text { hours }\end{array}$ & $\begin{array}{l}\text { RAW } 264.7 \\
\text { macrophages }\end{array}$ & $\begin{array}{l}\downarrow: \text { IL-1 } \beta \text {, IL-6, MMP9, } \\
\text { COX2, and iNOS } \\
\text { mRNAs }\end{array}$ \\
\hline$[45]$ & $\begin{array}{l}\text { Mouse primary splenocytes } \\
\text { treated with or without LPS }\end{array}$ & $0.8-3.3 \mu \mathrm{M}$ for 48 hours & Culture media & $\downarrow:$ TNF- $\alpha$, IL-6 \\
\hline$[46]$ & $\begin{array}{l}\text { NIT-1 pancreatic } \beta \text {-cells } \\
\text { treated with LPS }\end{array}$ & $1.25-5 \mu \mathrm{M}$ for 24 hours & Culture media & $\begin{array}{l}\downarrow: \text { TNF- } \alpha \text {, IL- } 6 \text {, and } \\
\text { MCP-1 }\end{array}$ \\
\hline$[47]$ & $\begin{array}{l}\text { KM mice, obesity and insulin } \\
\text { resistance induced by HFD } \\
\text { feeding for } 13 \text { weeks }\end{array}$ & $\begin{array}{l}50 \text { or } 150 \mathrm{mg} / \mathrm{kg} / \mathrm{d} \text {, p.o. for } 2 \\
\text { weeks }\end{array}$ & Serum & $\downarrow:$ TNF- $\alpha$, IL-6 \\
\hline$[48]$ & $\begin{array}{l}\text { Wistar rats, STZ } 50 \mathrm{mg} / \mathrm{kg} \text {, } \\
\text { single i.p. injection }\end{array}$ & $\begin{array}{l}100 \mathrm{mg} / \mathrm{kg} / \mathrm{d}, \mathrm{p} . \mathrm{o} . \text { for } 7 \\
\text { weeks }\end{array}$ & Serum & $\downarrow: \mathrm{CRP}$ \\
\hline$[49]$ & $\begin{array}{l}\text { Wistar rats, NAFLD and } \\
\text { insulin resistance induced by } \\
\text { HFD for } 8 \text { weeks }\end{array}$ & $\begin{array}{l}187.5 \mathrm{mg} / \mathrm{kg} / \mathrm{d} \text {, p.o. for } 4 \\
\text { weeks }\end{array}$ & Liver & $\begin{array}{l}\downarrow \text { : inflammatory cell } \\
\text { infiltration }\end{array}$ \\
\hline$[44]$ & $\mathrm{db} / \mathrm{db}$ mice & $5 \mathrm{mg} / \mathrm{kg} / \mathrm{d}$, i.p. for 4 weeks & White adipose tissue & $\begin{array}{l}\downarrow: \text { TNF- } \alpha, \text { IL-1 } \beta \text {, IL-6, } \\
\text { MCP-1, iNOS, and } \\
\text { COX2 mRNAs }\end{array}$ \\
\hline$[28]$ & $\begin{array}{l}\text { SD rats, STZ } 60 \mathrm{mg} / \mathrm{kg} \text {, single } \\
\text { tail vein injection }\end{array}$ & $\begin{array}{l}200 \mathrm{mg} / \mathrm{kg} / \mathrm{d} \text {, p.o. for } 12 \\
\text { weeks }\end{array}$ & Kidney & $\begin{array}{l}\downarrow: \text { ICAM-1, TGF- } \beta 1 \\
\text { protein expression }\end{array}$ \\
\hline$[50]$ & NOD mice & $\begin{array}{l}200 \mathrm{mg} / \mathrm{kg} / \mathrm{d} \text {, p.o. for } 2 \\
\text { weeks }\end{array}$ & $\begin{array}{l}\text { Supernatant from } \\
\text { splenocytes, CD } 4^{+} \mathrm{T} \\
\text { cells from spleen/lymph } \\
\text { nodes }\end{array}$ & $\begin{array}{l}\downarrow: \text { TNF- } \alpha, \text { IL-6, IFN } \gamma \text {, } \\
\text { and IL-17 }\end{array}$ \\
\hline \multirow[t]{2}{*}[51]{} & \multirow{2}{*}{ NOD mice } & \multirow{2}{*}{$\begin{array}{l}50,150 \text { and } 500 \mathrm{mg} / \mathrm{kg} / \mathrm{d} \text {, } \\
\text { p.o. for } 14 \text { weeks }\end{array}$} & $\begin{array}{l}\text { Supernatant from } \\
\text { splenocytes }\end{array}$ & $\begin{array}{l}\uparrow: \text { IL-10/IL-1 } \beta \text { and } \\
\text { IL-10/IL-6 ratios; } \downarrow \text { : } \\
\text { IFN } \gamma\end{array}$ \\
\hline & & & Kidney and liver & $\begin{array}{l}\uparrow: \text { IL-10/IL- } 6 \text { and } \\
\text { IL-10/TNF- } \alpha \text { ratios of } \\
\text { mRNA levels }\end{array}$ \\
\hline
\end{tabular}

$\downarrow$ : decrease, $\uparrow$ : increase; BBR: berberine, LPS: lipopolysaccharide, KM mice: Kunming mice, HFD: high fat diet, STZ: streptozotocin, NAFLD: nonalcoholic fatty liver disease, p.o.: per os/oral administration, i.p.: intraperitoneal, TNF- $\alpha$ : tumor necrosis factor- $\alpha$, IL: interleukin, CRP: C-reaction protein, HP: haptoglobin, MMP9: matrix metalloprotease 9, COX2: cyclooxygenase-2, iNOS: inducible nitric oxide synthase, MCP-1: monocyte chemoattractant protein 1, ICAM-1: intercellular adhesionmolecule-1, TGF- $\beta 1$ : transforming growth factor- $\beta 1$, IFN $\gamma$ : interferon- $\gamma$.

and GSH contents in cells and reduce ROS production and oxidative stress (Figure 1) [72-75].

\section{Anti-Inflammatory Activity and Mechanisms of BBR in the Treatment of Diabetes Mellitus}

3.1. BBR Reduced Inflammation Response in Diabetes Mellitus. The anti-inflammatory activity of BBR was observed both in vitro and in vivo and was noted by the reduction of proinflammatory cytokines as well as acute phase proteins (Table 2) [28, 42-51]. In cultured metabolic cells (adipocytes and liver cells), immunocytes (macrophages and splenocytes) or pancreatic $\beta$-cells, BBR treatment reduced the production of TNF- $\alpha$, IL- 6 , IL- $1 \beta$, matrix metalloprotease 9 (MMP9), cyclooxygenase-2 (COX2), inducible nitric oxide synthase (iNOS), monocyte chemoattractant protein 1 (MCP1 ), and C-reaction protein (CRP) and haptoglobin (HP) [42-46]. In insulin resistant HepG2 cells [43], the antiinflammatory activity of BBR was associated with its insulinsensitizing effect. BBR administration significantly decreased cytokine production, and reduced serine phosphorylation but increased insulin-mediated tyrosine phosphorylation of IRS in HepG2 cells treated with palmitate [43].

BBR could reduce proinflammatory cytokines, acute phase protein and infiltration of inflammatory cells in animals with diabetes mellitus or insulin resistance, either induced by STZ injection/HFD feeding or spontaneously happened (Table 2) [28, 44, 47-49]. In these animal models, the anti-inflammatory activity of BBR was observed in different tissues like serum, liver, adipose tissue, and kidney and was associated with its effect against insulin resistance or diabetes mellitus [28, 44, 47-49]. 
Notably, BBR was proved to inhibit inflammation and relieve the development of type 1 diabetes mellitus in NOD mice $[50,51]$. As shown in Table 2, BBR reduced the production of proinflammatory cytokines like TNF- $\alpha$, IL-6, interferon- $\gamma(\operatorname{IFN} \gamma)$, and IL-17 in NOD mice [50, 51]. Furthermore, BBR could increase the ratios of antiinflammatory/proinflammatory cytokines, like IL-10/IL-1 $\beta$, IL-10/IL-6 and IL-10/TNF- $\alpha$ [51]. The anti-inflammatory activity of BBR was observed in splenocytes, kidney, and liver of NOD mice [50, 51].

Besides evidences from cultured cells and diabetic animal models, the anti-inflammatory effect of BBR was also observed in clinic [77]. BBR therapy at a dose of $1 \mathrm{~g} /$ day for 3 months significantly reduced the serum IL- 6 level in patients with T2DM [77].

3.2. Mechanisms and Pathways of the Anti-Inflammatory Activity of BBR. BBR suppresses inflammation through complex mechanisms. Representative cellular pathways of BBR in inhibiting inflammation, which apparently shared in part with the antioxidant pathways, are summarized in Figure 1.

In addition to antioxidant activity, the AMPK pathway was also crucial for the anti-inflammatory efficacy of BBR $[44,72]$. Blocking AMPK could abolish the inhibitory effect of BBR on the production of proinflammatory cytokines, like iNOS and COX2 in macrophages (Figure 1) [44, 72]. Excessive iNOS in cells could cause overproduction of nitric oxide and had close relationship with the development of insulin resistance [78]. COX2 was a key enzyme for the synthesis of prostaglandins [79], which were important mediators for the pathogenesis of diabetes mellitus and diabetic nephropathy [80].

The anti-inflammatory activity of BBR was also associated with its inhibitory effect on the mitogen-activated protein kinase (MAPK) signaling pathways, which were activated by inflammatory stimuli $[44,46,81,82]$. The inhibitory effect of BBR on MAPKs was dependent on AMPK activation in macrophages [44]. It seems that conflicting results exist concerning the regulatory effect of BBR on MAPK signaling. Although some results suggested that BBR suppressed inflammation through inhibiting MAPKs [44, 46, 81, 82], others indicated that P38 was activated by BBR which was considered important for BBR's efficacy against oxidative stress and inflammation $[75,83]$. In reviewing published results, it seemed that BBR could increase P38 phosphorylation in unstimulated cells with baseline P38 activity [83], but decrease MAPK phosphorylation in cells treated with inflammatory stimuli like lipopolysaccharide (LPS), FFA and TNF- $\alpha$ which could activate MAPKs $[44,46,81,82]$.

There was discrepancy concerning the role of P38 in BBR-stimulated glucose metabolism as well. For example, BBR was shown to activate P38 and increase glucose uptake in L6 cells; and the effect of BBR on glucose metabolism could be partially blocked by a P38 inhibitor [84]. But in another report, the glucose uptake-stimulating effect of BBR was independent of P38 in adipocytes [85]. These results may suggest that as members of a complex signaling network, MAPKs could be regulated by BBR differentially; and their relationships to other signaling molecules and roles in the pharmacological effect of BBR need further study.

Besides antioxidant activity, the transcription factor of Nrf2 also played an important role in the anti-inflammatory activity of BBR (Figure 1) [72, 83]. Blocking Nrf2 abolished the inhibitory effect of $\mathrm{BBR}$ on the production of proinflammatory cytokines in macrophages $[72,83]$. BBR treatment could induce the activation of AMPK and P38, which in turn promote nuclear translocation of $\mathrm{Nrf} 2$, and inhibit the production of proinflammatory cytokines [72, 83].

$\mathrm{HO}-1$, an antioxidant enzyme whose expression was driven by Nrf2 [76], could be induced by BBR [72-75, 83]. Besides antioxidant activity [72-75], HO-1 was also involved in the anti-inflammatory activity of BBR, as blocking $\mathrm{HO}$ 1 with inhibitor could attenuate the inhibitory effect of BBR on the production of proinflammatory cytokines [83]. Now, a growing number of evidences proved that HO-1 was a very important molecule with integrated beneficial effects against insulin resistance, diabetes mellitus, oxidative stress and inflammation [86]. HO-1 could be a useful target for the development of novel anti-diabetic drugs in the future [87].

The NF- $\kappa$ B pathway plays a key role in controlling inflammation [14]; it is a critical target for the anti-inflammatory activity of BBR, as well (Figure 1 ). In NF- $\kappa \mathrm{B}$ signaling pathway, I $\kappa \mathrm{B}$ kinase $\beta$ (IKK- $\beta$ ) could be activated by inflammatory stimuli like TNF- $\alpha$, as well as nutritional factors like glucose and FFA $[10,14]$. The activation of IKK- $\beta$ required phosphorylation of the serine residue at position 181 $\left(\operatorname{ser}^{181}\right)[88,89]$. In insulin resistant 3T3-L1 adipocytes [90] and liver/adipose tissues from obese mice feed with HFD [47], BBR administration greatly reduced phosphorylation of $\operatorname{ser}^{181}$ and activation of IKK- $\beta$. In addition, the inhibitory effect of BBR on IKK- $\beta$ required a cysteine residue at position 179 of IKK- $\beta$ [91].

As inhibitory $\kappa \mathrm{B}-\alpha(\mathrm{I} \kappa \mathrm{B}-\alpha)$ was phosphorylated by IKK$\beta$ and then degraded $[88,89]$, inhibition of IKK- $\beta$ by BBR could result in the stabilization of $\mathrm{I} \kappa \mathrm{B}-\alpha[82,92,93]$, which in turn blocked the nuclear translocation of $\mathrm{NF}-\kappa \mathrm{B}[46,82$, $90,93,94]$. As a transcription factor, NF- $\kappa \mathrm{B}$ promoted the expression of various proinflammatory cytokines such as TNF- $\alpha$, IL- 6 , iNOS and COX2 $[10,14]$. In a variety of cells or tissues like pancreatic $\beta$-cells [46], nerve cells [82], lung cells [92], and rat kidney $[93,94]$ as well as in a mice model of insulin resistance [47], the inhibitory effect of BBR on the production of proinflammatory cytokines was related to its negative regulation of the NF- $\kappa \mathrm{B}$ signaling pathway.

Recent study proved that BBR could reduce renal inflammation in diabetic rats through inhibiting the Rho GTPase signaling pathway [28]. Rho GTPase was a member of the superfamily of small GTP binding proteins with multiple biological functions [95]; it was proved to positively regulate the NF- $\kappa$ B signaling pathway in diabetic rats [96]. So, in addition to regulation of the classic $\mathrm{NF}-\kappa \mathrm{B}$ signaling pathway, BBR could inhibit NF- $\kappa$ B by suppressing Rho GTPase [28, 96]. Furthermore, the inhibitory effect of BBR on Rho GTPase relied on its antioxidant activity [28].

In addition to NF- $\kappa \mathrm{B}$, transcription factor activator protein 1 (AP-1) also played a role in the anti-inflammatory 
activity of BBR [97, 98]. Like NF- $\kappa$ B, AP-1 was critical for the development of inflammation [99]. Administration of BBR to macrophages or epithelial cells greatly attenuated the DNA binding activity of AP- 1 and reduced the production of cytokines like MCP-1 and COX2 [97, 98].

There were reports that the transcription stimulating activity of AP- 1 and NF- $\kappa$ B could be inhibited by activation of peroxisome proliferator-activated receptor $\gamma(\operatorname{PPAR} \gamma)[100-$ 102]. BBR was reported to reduce the production of proinflammatory cytokines partially through PPAR $\gamma$ activation in macrophages and intestine $[103,104]$. It is possible that PPAR $\gamma$ activation may contribute in part to the inhibition of AP- 1 and NF- $\kappa$ B by BBR (Figure 1); direct experimental evidences are needed to support this presumption. However, the effect of BBR on PPAR $\gamma$ remains uncertain. Some reports showed that BBR treatment could activate PPAR $\gamma[103,104]$ or increase its expression in adipose tissues $[105,106]$, but others suggested that BBR downregulated the expression of $\operatorname{PPAR} \gamma$ in adipocytes $[107,108]$. The explanation for the difference is still unavailable.

\section{Discussion}

As a herbal compound, BBR was first reported to have glucose-lowering efficacy in 1986 in diabetic animals [109]. Then, in 1988, BBR was found to reduce the blood glucose level in patients with T2DM [110]. The molecular pharmacology of BBR in treating diabetes mellitus and insulin resistance was intensively studied in recent years and was reviewed in detail elsewhere [20-23]. Here in the present review, we summarized the activity of BBR against diabetes mellitus from a different point of view: the inhibitory effects of BBR on oxidative stress and inflammation.

From the view of metabolic disorders, inflammation and oxidative stress closely relates each other [14, 111, 112]. NF$\kappa \mathrm{B}$ is a master regulator of both inflammation reaction and oxidative stress $[10,14,111,112]$. Oxidative stress could stimulate the production of proinflammatory cytokines such as TNF- $\alpha$ and IL- 6 in the adipose tissue [3]. On the other hand, proinflammatory cytokines could also increase the amount of ROS in cells and promote oxidative stress [113]. It was obvious that a vicious cycle existed between oxidative stress and inflammation, which, in collaboration, could deteriorate insulin resistance $[14,111]$. BBR could reduce oxidative stress and inflammation through some of the common cellular signaling pathways, such as the AMPK pathway and $\mathrm{Nrf2} / \mathrm{HO}$ pathway $[72,83]$. It was rational to infer that BBR administration could terminate the vicious cycle between oxidative stress and inflammation. The inhibitory effect of BBR on the oxidative-inflammatory loop needs to be further studied.

BBR suppressed oxidative stress and inflammation through multiple mechanisms. In addition to what was mentioned above, recent studies indicated that the antiinflammatory activity of BBR was also associated with its beneficial effects in the gut [114-116]. Due to the possible low bioavailability [117], high concentration of BBR in the gut after oral administration could modulate the structure of gut microbiota, resulting in the enrichment of short-chain fatty acid (SCFA)-producing bacteria in the gut [114]. SCFA could improve intestinal barrier function and prevent inflammation by blocking exogenous antigen or endotoxin to enter into the blood [118]. This theory was supported by the observations that BBR could ameliorate intestinal barrier damage induced by TNF- $\alpha$ or LPS in cultured human colon monolayer or animal models [119-121].

On the other hand, while BBR seemed poorly absorbed in the gut, recent pharmacokinetic study [122] suggested that the concentrations of BBR (together with its metabolites) in organs (like the liver and kidney) were significantly higher than its blood concentration after oral administration in rats. This finding could partially explain the pharmacological activities of BBR in various tissues despite its low blood concentration $[117,122]$. Our previous work showed that the metabolites of BBR could activate AMPK, as well [123]. It will be interesting to investigate if BBR metabolites have any antioxidant or anti-inflammatory activity against diabetes mellitus.

Some of the key issues of BBR in reducing oxidative stress and inflammation still need to be further studied. For example, conflicting results in the regulation of UCP2, MAPKs, and PPAR $\gamma$ by BBR need to be clarified. The clinical outcome and significance of the antioxidant and antiinflammatory activities of BBR in treating diabetes mellitus need to be investigated. In addition, recent studies showed that BBR had beneficial effects against endoplasmic reticulum (ER) stress in insulin resistance and islet $\beta$-cell dysfunction $[124,125]$. ER stress, which could be induced by ROS and inflammation $[126,127]$, is a key factor for the pathogenesis of diabetes mellitus and has become an important therapeutic target in recent years [128]. Further investigation of the influence of BBR on ER stress and its relationship to oxidative stress/inflammation will help to clarify the pharmacology of BBR against diabetes mellitus and promote the research and development of antidiabetic natural products.

\section{Conclusion}

In summary, natural compound BBR has antioxidant and anti-inflammatory activities which might contribute in part to its therapeutic efficacies against diabetes mellitus and insulin resistance. Multiple cellular kinases as well as signaling pathways such as AMPK, MAPKs, Nrf2/HO pathway, and NF- $\kappa$ B pathway (Figure 1) were verified to be pivotal for $B B R$ in reducing oxidative stress and inflammation. Because of the increased interest in BBR's clinical uses in the past 10 years, the molecular details for the antioxidant and antiinflammatory activities of BBR merit further investigation.
Abbreviations
BBR: Cerberine
SIRT1: Sirtuin 1
FOXO: Forkhead box $\mathrm{O}$
NADPH: Nicotinamide adenine dinucleotide phosphate
SOD: $\quad$ Superoxide dismutase
AMPK: AMP-activated protein kinase
PI3K: Phosphatidylinositol 3-kinase 
Nrf2: Nuclear factor erythroid-2-related factor-2

UCP2: Uncoupling protein 2

GSH: Glutathione

NQO-1: NADPH quinine oxidoreductase-1

HO-1: Heme oxygenase-1

iNOS: Inducible nitric oxide synthase

COX2: Cyclooxygenase-2

ROS: $\quad$ Reactive oxygen species

MAPK: Mitogen-activated protein kinase

IKK- $\beta$ : I $\kappa$ B kinase $-\beta$

$\mathrm{I} \kappa \mathrm{B}-\alpha$ : Inhibitory $\kappa \mathrm{B}-\alpha$

NF- $\kappa$ B: Nuclear factor $-\kappa B$

AP-1: Activator protein 1

PPAR $\gamma$ : Peroxisome proliferator-activated receptor $\gamma$.

\section{Conflict of Interests}

The authors have no conflict of interests in this paper.

\section{Acknowledgment}

This work was supported by the National Mega-Project for Innovative Drugs (2012ZX09301-002-001-015).

\section{References}

[1] J. L. Evans, B. A. Maddux, and I. D. Goldfine, "The molecular basis for oxidative stress-induced insulin resistance," Antioxidants and Redox Signaling, vol. 7, no. 7-8, pp. 1040-1052, 2005.

[2] M. Y. Donath and S. E. Shoelson, "Type 2 diabetes as an inflammatory disease," Nature Reviews Immunology, vol. 11, no. 2, pp. 98-107, 2011.

[3] S. Furukawa, T. Fujita, M. Shimabukuro et al., "Increased oxidative stress in obesity and its impact on metabolic syndrome," The Journal of Clinical Investigation, vol. 114, no. 12, pp. 1752-1761, 2004.

[4] D. Bonnefont-Rousselot, "Glucose and reactive oxygen species," Current Opinion in Clinical Nutrition and Metabolic Care, vol. 5, no. 5, pp. 561-568, 2002.

[5] L. C. Alberici, A. E. Vercesi, and H. C. F. Oliveira, "Mitochondrial energy metabolism and redox responses to hypertriglyceridemia," Journal of Bioenergetics and Biomembranes, vol. 43, no. 1, pp. 19-23, 2011.

[6] P. Rösen, P. P. Nawroth, G. King, W. Möller, H.-J. Tritschler, and L. Packer, "The role of oxidative stress in the onset and progression of diabetes and its complications: a summary of a congress series sponsored by UNESCO-MCBN, the American diabetes association and the German diabetes society," Diabetes/Metabolism Research and Reviews, vol. 17, no. 3, pp. 189212, 2001.

[7] J. L. Evans, I. D. Goldfine, B. A. Maddux, and G. M. Grodsky, "Are oxidative stress-activated signaling pathways mediators of insulin resistance and $\beta$-cell dysfunction?" Diabetes, vol. 52, no. 1, pp. 1-8, 2003.

[8] H. Kaneto, G. Xu, N. Fujii, S. Kim, S. Bonner-Weir, and G. C. Weir, "Involvement of c-Jun N-terminal kinase in oxidative stress-mediated suppression of insulin gene expression," Journal of Biological Chemistry, vol. 277, no. 33, pp. 30010-30018, 2002.
[9] V. Scivittaro, M. B. Ganz, and M. F. Weiss, "AGEs induce oxidative stress and activate protein kinase C- $\beta$ (II) in neonatal mesangial cells," American Journal of Physiology, vol. 278, no. 4, pp. F676-F683, 2000.

[10] A. Goldin, J. A. Beckman, A. M. Schmidt, and M. A. Creager, "Advanced glycation end products: sparking the development of diabetic vascular injury," Circulation, vol. 114, no. 6, pp. 597605, 2006.

[11] W. Xie and L. Du, "Diabetes is an inflammatory disease: evidence from traditional Chinese medicines," Diabetes, Obesity and Metabolism, vol. 13, no. 4, pp. 289-301, 2011.

[12] M. Crook, "Type 2 diabetes mellitus: a disease of the innate immune system? An update," Diabetic Medicine, vol. 21, no. 3, pp. 203-207, 2004.

[13] M. Y. Donath, "Targeting inflammation in the treatment of type 2 diabetes," Diabetes, Obesity and Metabolism, vol. 15, supplement 3, pp. 193-196, 2013.

[14] A. Gratas-Delamarche, F. Derbré, S. Vincent, and J. Cillard, "Physical inactivity, insulin resistance, and the oxidativeinflammatory loop," Free Radical Research, vol. 48, no. 1, pp. 93108, 2014.

[15] F. Mahmoud and E. Al-Ozairi, "Inflammatory cytokines and the risk of cardiovascular complications in type 2 diabetes," Disease Markers, vol. 35, no. 4, pp. 235-241, 2013.

[16] P. S. Patel, E. D. Buras, and A. Balasubramanyam, "The role of the immune system in obesity and insulin resistance," Journal of Obesity, Article ID 616193, 2013.

[17] H.-Y. Hung, K. Qian, S. L. Morris-Natschke, C.-S. Hsu, and K.H. Lee, "Recent discovery of plant-derived anti-diabetic natural products," Natural Product Reports, vol. 29, no. 5, pp. 580-606, 2012.

[18] J. Yin, H. Zhang, and J. Ye, "Traditional Chinese medicine in treatment of metabolic syndrome," Endocrine, Metabolic and Immune Disorders, vol. 8, no. 2, pp. 99-111, 2008.

[19] J. Yao, W. Kong, and J. Jiang, "Learning from berberine: treating chronic diseases through multiple targets," Science China Life Science, 2013.

[20] J. Yin, J. Ye, and W. Jia, "Effects and mechanisms of berberine in diabetes treatment," Acta Pharmaceutica Sinica B, vol. 2, no. 4, pp. 327-334, 2012.

[21] M. Zhang and L. Chen, "Berberine in type 2 diabetes therapy: a new perspective for an old antidiarrheal drug," Acta Pharmaceutica Sinica B, vol. 2, no. 4, pp. 379-386,, 2012.

[22] Y. Liu, L. Zhang, H. Song, and G. Ji, "Update on berberine in nonalcoholic Fatty liver disease," Evidence-Based Complementary and Alternative Medicine, vol. 2013, Article ID 308134, 8 pages, 2013.

[23] H. Dong, N. Wang, L. Zhao, and F. Lu, "Berberine in the treatment of type 2 diabetes mellitus: a systemic review and metaanalysis," Evidence-Based Complementary and Alternative Medicine, vol. 2012, Article ID 591654, 12 pages, 2012.

[24] H. Zhang, J. Wei, R. Xue et al., "Berberine lowers blood glucose in type 2 diabetes mellitus patients through increasing insulin receptor expression," Metabolism, vol. 59, no. 2, pp. 285-292, 2010.

[25] W.-J. Kong, H. Zhang, D.-Q. Song et al., "Berberine reduces insulin resistance through protein kinase C-dependent upregulation of insulin receptor expression," Metabolism, vol. 58, no. 1, pp. 109-119, 2009.

[26] H. Zhang, W.-J. Kong, Y.-Q. Shan et al., "Protein kinase D activation stimulates the transcription of the insulin receptor 
gene," Molecular and Cellular Endocrinology, vol. 330, no. 1-2, pp. 25-32, 2010.

[27] W.-H. Liu, Z.-Q. Hei, H. Nie et al., "Berberine ameliorates renal injury in streptopzotocin-induced diabetic rats by suppression of both oxidative stress and aldose reductase," Chinese Medical Journal, vol. 121, no. 8, pp. 706-712, 2008.

[28] X. Xie, X. Chang, L. Chen et al., "Berberine ameliorates experimental diabetes-induced renal inflammation and fibronectin by inhibiting the activation of RhoA/ROCK signaling," Molecular and Cellular Endocrinology, vol. 381, pp. 56-65, 2013.

[29] J.-Y. Zhou and S.-W. Zhou, "Protective effect of berberine on antioxidant enzymes and positive transcription elongation factor b expression in diabetic rat liver," Fitoterapia, vol. 82, no. 2, pp. 184-189, 2011.

[30] T. Lao-ong, W. Chatuphonprasert, N. Nemoto, and K. Jarukamjorn, "Alteration of hepatic glutathione peroxidase and superoxide dismutase expression in streptozotocin-induced diabetic mice by berberine," Pharmaceutical Biology, vol. 50, no. 8, pp. 1007-1012, 2012.

[31] Y. Wang, T. Campbell, B. Perry, C. Beaurepaire, and L. Qin, "Hypoglycemic and insulin-sensitizing effects of berberine in high-fat diet- and streptozotocin-induced diabetic rats," Metabolism, vol. 60, no. 2, pp. 298-305, 2011.

[32] W. Chatuphonprasert, T. Lao-Ong, and K. Jarukamjorn, "Improvement of superoxide dismutase and catalase in streptozotocin-nicotinamide-induced type 2 -diabetes in mice by berberine and glibenclamide," Pharmaceutical Biology, 2013.

[33] D. Wu, W. Wen, C.-L. Qi et al., "Ameliorative effect of berberine on renal damage in rats with diabetes induced by high-fat diet and streptozotocin," Phytomedicine, vol. 19, no. 8-9, pp. 712-718, 2012.

[34] J. Zhou, S. Zhou, J. Tang et al., "Protective effect of berberine on beta cells in streptozotocin- and high-carbohydrate/high-fat diet-induced diabetic rats," European Journal of Pharmacology, vol. 606, no. 1-3, pp. 262-268, 2009.

[35] L.-Q. Tang, W. Wei, L.-M. Chen, and S. Liu, "Effects of berberine on diabetes induced by alloxan and a high-fat/high-cholesterol diet in rats," Journal of Ethnopharmacology, vol. 108, no. 1, pp. 109-115, 2006.

[36] P. Bhutada, Y. Mundhada, K. Bansod et al., "Protection of cholinergic and antioxidant system contributes to the effect of berberine ameliorating memory dysfunction in rat model of streptozotocin-induced diabetes," Behavioural Brain Research, vol. 220, no. 1, pp. 30-41, 2011.

[37] H. K. Moghaddam, T. Baluchnejadmojarad, M. Roghani et al., "Berberine ameliorate oxidative stress and astrogliosis in the hippocampus of STZ-induced diabetic rats," Molecular Neurobiology, 2013.

[38] W. Liu, P. Liu, S. Tao et al., "Berberine inhibits aldose reductase and oxidative stress in rat mesangial cells cultured under high glucose," Archives of Biochemistry and Biophysics, vol. 475, no. 2, pp. 128-134, 2008.

[39] D. Del Rio, A. J. Stewart, and N. Pellegrini, "A review of recent studies on malondialdehyde as toxic molecule and biological marker of oxidative stress," Nutrition, Metabolism and Cardiovascular Diseases, vol. 15, no. 4, pp. 316-328, 2005.

[40] I. Ceballos-Picot, V. Witko-Sarsat, M. Merad-Boudia et al., "Glutathione antioxidant system as a marker of oxidative stress in chronic renal failure," Free Radical Biology and Medicine, vol. 21, no. 6, pp. 845-853, 1996.
[41] A. C. Maritim, R. A. Sanders, and J. B. Watkins III, "Diabetes, oxidative stress, and antioxidants: a review," Journal of Biochemical and Molecular Toxicology, vol. 17, no. 1, pp. 24-38, 2003.

[42] B.-H. Choi, I.-S. Ahn, Y.-H. Kim et al., "Berberine reduces the expression of adipogenic enzymes and inflammatory molecules of 3T3-L1 adipocyte," Experimental and Molecular Medicine, vol. 38, no. 6, pp. 599-605, 2006.

[43] T. Lou, Z. Zhang, Z. Xi et al., "Berberine inhibits inflammatory response and ameliorates insulin resistance in hepatocytes," Inflammation, vol. 34, no. 6, pp. 659-667, 2011.

[44] H. W. Jeong, K. C. Hsu, J.-W. Lee et al., "Berberine suppresses proinflammatory responses through AMPK activation in macrophages," American Journal of Physiology - Endocrinology and Metabolism, vol. 296, no. 4, pp. E955-E964, 2009.

[45] W.-C. Lin and J.-Y. Lin, "Five bitter compounds display different anti-inflammatory effects through modulating cytokine secretion using mouse primary splenocytes in vitro," Journal of Agricultural and Food Chemistry, vol. 59, no. 1, pp. 184-192, 2011.

[46] Y. Wang, "Attenuation of berberine on lipopolysaccharideinduced inflammatory and apoptosis responses in $\beta$-cells via TLR4-independent JNK/NF- $\kappa$ B pathway," Pharmaceutical Biology, 2013.

[47] W. Shang, J. Liu, X. Yu, and J. Zhao, "Effects of berberine on serum levels of inflammatory factors and inflammatory signaling pathway in obese mice induced by high fat diet," Zhongguo Zhongyao Zazhi, vol. 35, no. 11, pp. 1474-1477, 2010.

[48] Y. Chen, Y. Wang, J. Zhang, C. Sun, and A. Lopez, "Berberine improves glucose homeostasis in streptozotocin-induced diabetic rats in association with multiple factors of insulin resistance," ISRN Endocrinology, vol. 2011, Article ID 519371, 2011.

[49] L.-J. Xing, L. Zhang, T. Liu, Y.-Q. Hua, P.-Y. Zheng, and G. Ji, "Berberine reducing insulin resistance by up-regulating IRS-2 mRNA expression in nonalcoholic fatty liver disease (NAFLD) rat liver," European Journal of Pharmacology, vol. 668, no. 3, pp. 467-471, 2011.

[50] G. Cui, X. Qin, Y. Zhang, Z. Gong, B. Ge, and Y. Q. Zang, "Berberine differentially modulates the activities of ERK, p38 MAPK, and JNK to suppress Th17 and Th1 T cell differentiation in type 1 diabetic mice," Journal of Biological Chemistry, vol. 284, no. 41, pp. 28420-28429, 2009.

[51] W.-H. Chueh and J.-Y. Lin, "Protective effect of isoquinoline alkaloid berberine on spontaneous inflammation in the spleen, liver and kidney of non-obese diabetic mice through downregulating gene expression ratios of pro-/anti-inflammatory and Th1/Th2 cytokines," Food Chemistry, vol. 131, no. 4, pp. 12631271, 2012.

[52] J. B. Majithiya and R. Balaraman, "Time-dependent changes in antioxidant enzymes and vascular reactivity of aorta in streptozotocin-induced diabetic rats treated with curcumin," Journal of Cardiovascular Pharmacology, vol. 46, no. 5, pp. 697-705, 2005.

[53] C. Hill, A. Flyvbjerg, H. Grønbæk et al., “The renal expression of transforming growth factor- $\beta$ isoforms and their receptors in acute and chronic experimental diabetes in rats," Endocrinology, vol. 141, no. 3, pp. 1196-1208, 2000.

[54] H. Mulder, B. Ahrén, and F. Sundler, "Islet amyloid polypeptide (amylin) and insulin are differentially expressed in chronic diabetes induced by streptozotocin in rats," Diabetologia, vol. 39, no. 6, pp. 649-657, 1996.

[55] A. Shirwaikar, A. Shirwaikar, K. Rajendran, and I. S. R. Punitha, "In vitro antioxidant studies on the benzyl tetra isoquinoline 
alkaloid berberine," Biological and Pharmaceutical Bulletin, vol. 29, no. 9, pp. 1906-1910, 2006.

[56] X. Zhu, X. Guo, G. Mao et al., "Hepatoprotection of berberine against hydrogen peroxide-induced apoptosis by upregulation of Sirtuin 1," Phytotherapy Research, vol. 27, no. 3, pp. 417-421, 2013.

[57] A. Salminen, K. Kaarniranta, and A. Kauppinen, "Crosstalk between oxidative stress and SIRT1: impact on the aging process," International Journal of Molecular Sciences, vol. 14, no. 2, pp. 3834-3859, 2013.

[58] A. van der Horst, L. G. J. Tertoolen, L. M. M. De Vries-Smits, R. A. Frye, R. H. Medema, and B. M. T. Burgering, " $\mathrm{FOXO}_{4}$ is acetylated upon peroxide stress and deacetylated by the longevity protein hSir ${ }^{\text {SIRT1 }, " ~ T h e ~ J o u r n a l ~ o f ~ B i o l o g i c a l ~ C h e m i s t r y, ~}$ vol. 279, no. 28, pp. 28873-28879, 2004.

[59] L. K. Sarna, N. Wu, S.-Y. Hwang, Y. L. Siow, and O. Karmin, "Berberine inhibits NADPH oxidase mediated superoxide anion production in macrophages," Canadian Journal of Physiology and Pharmacology, vol. 88, no. 3, pp. 369-378, 2010.

[60] F. Cheng, Y. Wang, J. Li et al., "Berberine improves endothelial function by reducing endothelial microparticles-mediated oxidative stress in humans," International Journal of Cardiology, vol. 167, no. 3, pp. 936-942, 2013.

[61] S. P. Gray, E. Di Marco, J. Okabe et al., "NADPH oxidase 1 plays a key role in diabetes mellitus-accelerated atherosclerosis," Circulation, vol. 127, no. 18, pp. 1888-1902, 2013.

[62] J.-M. Li and A. M. Shah, "ROS generation by nonphagocytic NADPH oxidase: potential relevance in diabetic nephropathy," Journal of the American Society of Nephrology, vol. 14, supplement 3, pp. S221-S226, 2003.

[63] A. A. Eid, B. M. Ford, K. Block et al., "AMP-activated Protein Kinase (AMPK) negatively regulates Nox4-dependent activation of p53 and epithelial cell apoptosis in diabetes," The Journal of Biological Chemistry, vol. 285, no. 48, pp. 37503-37512, 2010.

[64] S. Wang, M. Zhang, B. Liang et al., "AMPK $\alpha 2$ Deletion causes aberrant expression and activation of NAD(P)H Oxidase and consequent endothelial dysfunction in vivo: role of $26 \mathrm{~S}$ proteasomes," Circulation Research, vol. 106, no. 6, pp. 1117-1128, 2010.

[65] D. Kukidome, T. Nishikawa, K. Sonoda et al., "Activation of AMP-activated protein kinase reduces hyperglycemia-induced mitochondrial reactive oxygen species production and promotes mitochondrial biogenesis in human umbilical vein endothelial cells," Diabetes, vol. 55, no. 1, pp. 120-127, 2006.

[66] Z. Xie, J. Zhang, J. Wu, B. Viollet, and M.-H. Zou, "Upregulation of mitochondrial uncoupling protein- 2 by the AMP-Activated protein kinase in endothelial cells attenuates oxidative stress in diabetes," Diabetes, vol. 57, no. 12, pp. 3222-3230, 2008.

[67] Q. Wang, M. Zhang, B. Liang, N. Shirwany, Y. Zhu, and M.-H. Zou, "Activation of AMP-activated protein kinase is required for berberine-induced reduction of atherosclerosis in mice: the role of uncoupling protein 2," PLoS ONE, vol. 6, no. 9, Article ID e25436, 2011.

[68] A. Nègre-Salvayre, C. Hirtz, G. Carrera et al., "A role for uncoupling protein-2 as a regulator of mitochondrial hydrogen peroxide generation," The FASEB Journal, vol. 11, no. 10, pp. 809815, 1997.

[69] D. Arsenijevic, H. Onuma, C. Pecqueur et al., "Disruption of the uncoupling protein-2 gene in mice reveals a role in immunity and reactive oxygen species production," Nature Genetics, vol. 26, no. 4, pp. 435-439, 2000.

[70] Q.-H. Yang, S.-P. Hu, Y.-P. Zhang et al., "Effect of berberine on expressions of uncoupling protein-2 mRNA and protein in hepatic tissue of non-alcoholic fatty liver disease in rats," Chinese Journal of Integrative Medicine, vol. 17, no. 3, pp. 205211, 2011.

[71] B. M. de Souza, T. S. Assmann, L. M. Kliemann, J. L. Gross, L. H. Canani, and D. Crispim, "The role of uncoupling protein 2 (UCP2) on the development of type 2 diabetes mellitus and its chronic complications," Arquivos Brasileiros de Endocrinologia e Metabologia, vol. 55, no. 4, pp. 239-248, 2011.

[72] C. Mo, L. Wang, J. Zhang et al., "The crosstalk between Nrf2 and AMPK signal pathways is important for the anti-inflammatory effect of berberine in LPS-stimulated macrophages and endotoxin-shocked mice," Antioxidants \& Redox Signaling, 2013.

[73] Y.-Y. Hsu, C.-S. Chen, S.-N. Wu, Y.-J. Jong, and Y.-C. Lo, "Berberine activates Nrf2 nuclear translocation and protects against oxidative damage via a phosphatidylinositol 3-kinase/ Akt-dependent mechanism in NSC34 motor neuron-like cells," European Journal of Pharmaceutical Sciences, vol. 46, no. 5, pp. 415-425, 2012.

[74] Y. Y. Hsu, Y. T. Tseng, and Y. C. Lo, "Berberine, a natural antidiabetes drug, attenuates glucose neurotoxicity and promotes Nrf2-related neurite outgrowth," Toxicology and Applied Pharmacology, vol. 272, no. 3, pp. 787-796, 2013.

[75] J. Bae, D. Lee, Y. K. Kim, M. Gil, J. Y. Lee, and K. J. Lee, "Berberine protects 6-hydroxydopamine-induced human dopaminergic neuronal cell death through the induction of heme oxygenase-1," Molecules and Cells, vol. 35, no. 2, pp. 151157, 2013.

[76] E. E. Vomhof-Dekrey and M. J. Picklo Sr, “The Nrf2-antioxidant response element pathway: a target for regulating energy metabolism," Journal of Nutritional Biochemistry, vol. 23, no. 10, pp. 1201-1206, 2012.

[77] Y. Zhang, X. Li, D. Zou et al., "Treatment of type 2 diabetes and dyslipidemia with the natural plant alkaloid berberine," The Journal of Clinical Endocrinology and Metabolism, vol. 93, no. 7, pp. 2559-2565, 2008.

[78] M. Perreault and A. Marette, "Targeted disruption of inducible nitric oxide synthase protects against obesity-linked insulin resistance in muscle," Nature Medicine, vol. 7, no. 10, pp. 11381143, 2001.

[79] R. N. DuBois, S. B. Abramson, L. Crofford et al., "Cyclooxygenase in biology and disease," The FASEB Journal, vol. 12, no. 12, pp. 1063-1073, 1998.

[80] A. Mima, "Inflammation and oxidative stress in diabetic nephropathy: new insights on its inhibition as new therapeutic targets," Journal of Diabetes Research, vol. 2013, Article ID 248563, 8 pages, 2013.

[81] Q. Wang, J. Qi, R. Hu, Y. Chen, A. Kijlstra, and P. Yang, "Effect of berberine on proinflammatory cytokine production by ARPE19 cells following stimulation with tumor necrosis factor- $\alpha$," Investigative Ophthalmology \& Visual Science, vol. 53, no. 4, pp. 2395-2402, 2012.

[82] L. Jia, J. Liu, Z. Song et al., "Berberine suppresses amyloidbeta-induced inflammatory response in microglia by inhibiting nuclear factor-kappaB and mitogen-activated protein kinase signalling pathways," Journal of Pharmcy and Pharmacology, vol. 64, no. 10, pp. 1510-1521, 2012.

[83] D. Lee, J. Bae, Y. K. Kim et al., "Inhibitory effects of berberine on lipopolysaccharide-induced inducible nitric oxide synthase and the high-mobility group box 1 release in macrophages," Biochemical and Biophysical Research Communications, vol. 431, no. 3, pp. 506-511, 2013. 
[84] Z. Cheng, T. Pang, M. Gu et al., "Berberine-stimulated glucose uptake in L6 myotubes involves both AMPK and p38 MAPK," Biochimica et Biophysica Acta, vol. 1760, no. 11, pp. 1682-1689, 2006.

[85] L. Zhou, Y. Yang, X. Wang et al., "Berberine stimulates glucose transport through a mechanism distinct from insulin," Metabolism, vol. 56, no. 3, pp. 405-412, 2007.

[86] J. F. Ndisang, "Role of heme oxygenase in inflammation, insulin-signalling, diabetes and obesity," Mediators of Inflammation, vol. 2010, Article ID 359732, 2010.

[87] Y. Son, J. H. Lee, H. T. Chung, and H. O. Pae, “Therapeutic roles of heme oxygenase-1 in metabolic diseases: curcumin and resveratrol analogues as possible Inducers of heme oxygenase-1," Oxidative Medicine and Cellular Longevity, vol. 2013, Article ID 639541, 12 pages, 2013.

[88] F. Mercurio, H. Zhu, B. W. Murray et al., "IKK-1 and IKK-2: cytokine-activated I $\kappa$ B kinases essential for NF- $\kappa$ B activation," Science, vol. 278, no. 5339, pp. 860-866, 1997.

[89] M. Karin, "Positive and negative regulation of $\mathrm{I} \kappa \mathrm{B}$ kinase activity through IKK $\beta$ subunit phosphorylation," Science, vol. 284, no. 5412, pp. 309-313, 1999.

[90] P. Yi, F.-E. Lu, L.-J. Xu, G. Chen, H. Dong, and K.-F. Wang, "Berberine reverses free-fatty-acid-induced insulin resistance in 3T3-L1 adipocytes through targeting IKK $\beta$," World Journal of Gastroenterology, vol. 14, no. 6, pp. 876-883, 2008.

[91] M. K. Pandey, B. Sung, A. B. Kunnumakkara, G. Sethi, M. M. Chaturvedi, and B. B. Aggarwal, "Berberine modifies cysteine 179 of $\mathrm{I} \kappa \mathrm{B} \alpha$ kinase, suppresses nuclear factor- $\kappa \mathrm{B}$-regulated antiapoptotic gene products, and potentiates apoptosis," Cancer Research, vol. 68, no. 13, pp. 5370-5379, 2008.

[92] C.-H. Lee, J.-C. Chen, C.-Y. Hsiang, S.-L. Wu, H.-C. Wu, and T.-Y. Ho, "Berberine suppresses inflammatory agents-induced interleukin- $\beta$ and tumor necrosis factor- $\alpha$ productions via the inhibition of $\mathrm{I} \kappa \mathrm{B}$ degradation in human lung cells," Pharmacological Research, vol. 56, no. 3, pp. 193-201, 2007.

[93] Q. Jiang, P. Liu, X. Wu et al., "Berberine attenuates lipopolysaccharide-induced extracelluar matrix accumulation and inflammation in rat mesangial cells: involvement of NF- $\kappa \mathrm{B}$ signaling pathway," Molecular and Cellular Endocrinology, vol. 331, no. 1, pp. 34-40, 2011.

[94] X. Wan, X. Chen, L. Liu et al., "Berberine ameliorates chronic kidney injury caused by atherosclerotic renovascular disease through the suppression of NF $\kappa$ B signaling pathway in rats," PLoS ONE, vol. 8, no. 3, Article ID e59794, 2013.

[95] J. Shi and L. Wei, "Rho kinases in cardiovascular physiology and pathophysiology: the effect of fasudil," Journal of Cardiovascular Pharmacology, vol. 62, no. 4, pp. 341-354, 2013.

[96] X. Xie, J. Peng, X. Chang et al., "Activation of RhoA/ROCK regulates NF- $\kappa \mathrm{B}$ signaling pathway in experimental diabetic nephropathy," Molecular and Cellular Endocrinology, vol. 369, no. 1-2, pp. 86-97, 2013.

[97] A. Remppis, F. Bea, H. J. Greten et al., "Rhizoma coptidis inhibits LPS-induced MCP-1/CCL2 production in murine macrophages via an AP-1 and NF B-dependent pathway," Mediators of Inflammation, vol. 2010, Article ID 194896, 8 pages, 2010.

[98] C.-L. Kuo, C.-W. Chi, and T.-Y. Liu, "The anti-inflammatory potential of berberine in vitro and in vivo," Cancer Letters, vol. 203, no. 2, pp. 127-137, 2004.

[99] H. B. Schonthaler, J. Guinea-Viniegra, and E. F. Wagner, “Targeting inflammation by modulating the Jun/AP-1 pathway," Annals of the Rheumatic Diseases, vol. 70, no. 1, pp. i109-i112, 2011.
[100] M. Ricote, A. C. Li, T. M. Willson, C. J. Kelly, and C. K. Glass, "The peroxisome proliferator-activated receptor- $\gamma$ is a negative regulator of macrophage activation," Nature, vol. 391, no. 6662, pp. 79-82, 1998.

[101] P. Delerive, F. Martin-Nizard, G. Chinetti et al., "Peroxisome proliferator-activated receptor activators inhibit thrombininduced endothelin-1 production in human vascular endothelial cells by inhibiting the activator protein-1 signaling pathway," Circulation Research, vol. 85, no. 5, pp. 394-402, 1999.

[102] V. Pasceri, H. D. Wu, J. T. Willerson, and E. T. H. Yeh, "Modulation of vascular inflammation in vitro and in vivo by peroxisome proliferator-activated receptor- $\gamma$ activators," Circulation, vol. 101, no. 3, pp. 235-238, 2000.

[103] F. L. Chen, Z. H. Yang, Y. Liu et al., "Berberine inhibits the expression of TNFalpha, MCP-1, and IL-6 in AcLDL-stimulated macrophages through PPARgamma pathway," Endocrine, vol. 33, no. 3, pp. 331-337, 2008.

[104] A.-W. Feng, W. Gao, G.-R. Zhou et al., "Berberine ameliorates COX-2 expression in rat small intestinal mucosa partially through PPAR $\gamma$ pathway during acute endotoxemia," International Immunopharmacology, vol. 12, no. 1, pp. 182-188, 2012.

[105] J. Zhou and S. Zhou, "Berberine regulates peroxisome proliferator-activated receptors and positive transcription elongation factor b expression in diabetic adipocytes," European Journal of Pharmacology, vol. 649, no. 1-3, pp. 390-397, 2010.

[106] G.-S. Li, X.-H. Liu, H. Zhu et al., "Berberine-improved visceral white adipose tissue insulin resistance associated with altered sterol regulatory element-binding proteins, liver $\mathrm{X}$ receptors, and peroxisome proliferator-activated receptors transcriptional programs in diabetic hamsters," Biological and Pharmaceutical Bulletin, vol. 34, no. 5, pp. 644-654, 2011.

[107] J. Yang, J. Yin, H. Gao et al., "Berberine improves insulin sensitivity by inhibiting fat store and adjusting adipokines profile in human preadipocytes and metabolic syndrome patients," Evidence-based Complementary and Alternative Medicine, vol. 2012, Article ID 363845, 9 pages, 2012.

[108] C. Huang, Y. Zhang, Z. Gong et al., "Berberine inhibits 3T3L1 adipocyte differentiation through the PPAR $\gamma$ pathway," Biochemical and Biophysical Research Communications, vol. 348, no. 2, pp. 571-578, 2006.

[109] Q. M. Chen and M. Z. Xie, "Studies on the hypoglycemic effect of Coptis chinensis and berberine," Acta Pharmaceutica Sinica, vol. 21, no. 6, pp. 401-406, 1986.

[110] Y. X. Ni, “Therapeutic effect of berberine on 60 patients with type II diabetes mellitus and experimental research," Zhong Xi Yi Jie He Za Zhi, vol. 8, no. 12, pp. 711-713, 1988.

[111] J. Lugrin, N. Rosenblatt-Velin, R. Parapanov, and L. Liaudet, "The role of oxidative stress during inflammatory processes," Biological Chemistry, 2013.

[112] A. Muñoz and M. Costa, "Nutritionally mediated oxidative stress and inflammation," Oxidative Medicine and Cellular Longevity, vol. 2013, Article ID 610950, 2013.

[113] S. S. Soskić, B. D. Dobutović, E. M. Sudar et al., "Regulation of inducible Nitric Oxide synthase (iNOS) and its potential role in insulin resistance, diabetes and heart failure," Open Cardiovascular Medicine Journal, vol. 5, no. 1, pp. 153-163, 2011.

[114] X. Zhang, Y. Zhao, M. Zhang et al., "Structural changes of gut microbiota during berberine-mediated prevention of obesity and insulin resistance in high-fat diet-fed rats," PLOS ONE, vol. 7, no. 8, Article ID e42529, 2012.

[115] W. Xie, D. Gu, J. Li, K. Cui, and Y. Zhang, "Effects and action mechanisms of berberine and rhizoma coptidis on gut microbes 
and obesity in high-fat diet-fed C57BL/6 $\mathrm{J}$ mice," PLoS ONE, vol. 6, no. 9, Article ID e24520, 2011.

[116] J. Han, H. Lin, and W. Huang, "Modulating gut microbiota as an anti-diabetic mechanism of berberine," Medical Science Monitor, vol. 17, no. 7, pp. RA164-RA167, 2011.

[117] Y. Q. Shan, Y. P. Zhu, J. Pang et al., “Tetrandrine potentiates the hypoglycemic efficacy of berberine by inhibiting P-glycoprotein function," Biological and Pharmaceutical Bulletin, vol. 36, no. 10, pp. 1562-1569, 2013.

[118] L. Peng, Z.-R. Li, R. S. Green, I. R. Holzman, and J. Lin, "Butyrate enhances the intestinal barrier by facilitating tight junction assembly via activation of AMP-activated protein kinase in Caco-2 cell monolayers," Journal of Nutrition, vol. 139, no. 9, pp. 1619-1625, 2009.

[119] Q. Zhang, X.-L. Piao, X.-S. Piao, T. Lu, D. Wang, and S. W. Kim, "Preventive effect of Coptis chinensis and berberine on intestinal injury in rats challenged with lipopolysaccharides," Food and Chemical Toxicology, vol. 49, no. 1, pp. 61-69, 2011.

[120] M. Amasheh, A. Fromm, S. M. Krug et al., "TNF $\alpha$-induced and berberine-antagonized tight junction barrier impairment via tyrosine kinase, Akt and NFאB signaling," Journal of Cell Science, vol. 123, no. 23, pp. 4145-4155, 2010.

[121] L. Gu, N. Li, J. Gong, Q. Li, W. Zhu, and J. Li, "Berberine ameliorates intestinal epithelial tight-junction damage and down-regulates myosin light chain kinase pathways in a mouse model of endotoxinemia," Journal of Infectious Diseases, vol. 203, no. 11, pp. 1602-1612, 2011.

[122] X. S. Tan, J. Y. Ma, R. Feng et al., "Tissue distribution of berberine and its metabolites after oral administration in rats," PLoS ONE, vol. 8, no. 10, Article ID e77969, 2013.

[123] Y. X. Wang, W. J. Kong, Y. H. Li et al., "Synthesis and structure-activity relationship of berberine analogues in LDLR up-regulation and AMPK activation," Bioorganic \& Medicinal Chemistry, vol. 20, no. 22, pp. 6552-6558, 2012.

[124] Z.-S. Wang, F.-E. Lu, L.-J. Xu, and H. Dong, "Berberine reduces endoplasmic reticulum stress and improves insulin signal transduction in Hep G2 cells," Acta Pharmacologica Sinica, vol. 31, no. 5, pp. 578-584, 2010.

[125] S. Wu, F. E. Lu, H. Dong et al., "Effect of berberine on the endoplasmic reticulum stress-related apoptosis in pancreatic $\beta$ cells," Chinese Journal of Diabetes, vol. 21, no. 6, pp. 544-547, 2013.

[126] X. Xue, J.-H. Piao, A. Nakajima et al., "Tumor necrosis factor $\alpha(\mathrm{TNF} \alpha)$ induces the unfolded protein response (UPR) in a reactive oxygen species (ROS)-dependent fashion, and the UPR counteracts ROS accumulation by TNF $\alpha$," Journal of Biological Chemistry, vol. 280, no. 40, pp. 33917-33925, 2005.

[127] S. Hanada, M. Harada, H. Kumemura et al., "Oxidative stress induces the endoplasmic reticulum stress and facilitates inclusion formation in cultured cells," Journal of Hepatology, vol. 47, no. 1, pp. 93-102, 2007.

[128] C. Evans-Molina, M. Hatanaka, and R. G. Mirmira, "Lost in translation: endoplasmic reticulum stress and the decline of $\beta$-cell health in diabetes mellitus," Diabetes, Obesity and Metabolism, vol. 15, supplement 3, pp. 159-169, 2013. 


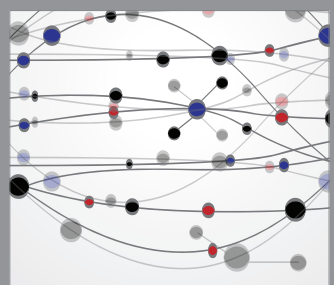

The Scientific World Journal
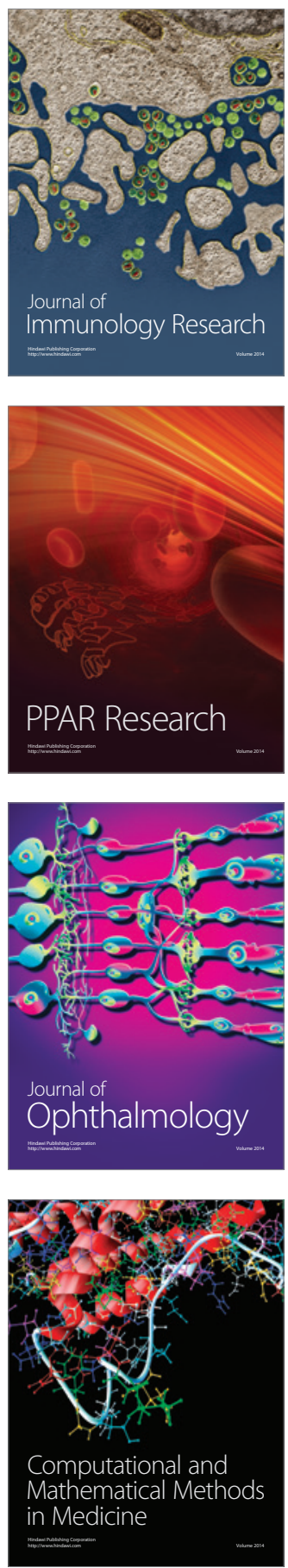

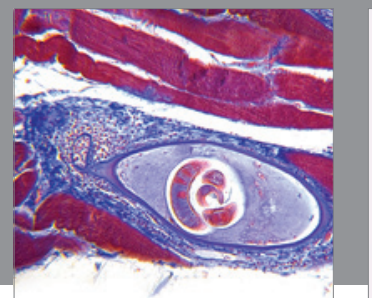

Gastroenterology

Research and Practice
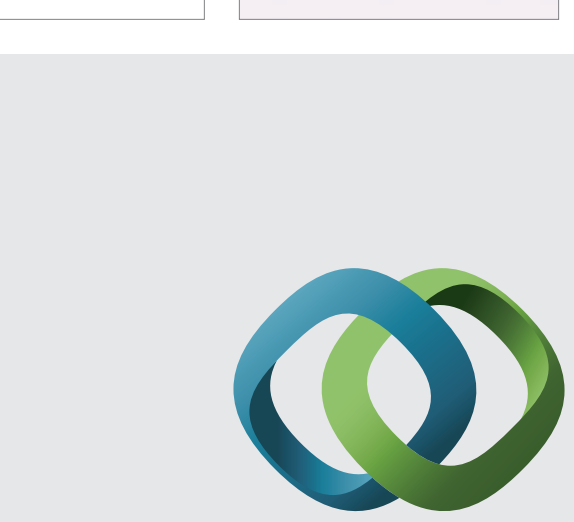

\section{Hindawi}

Submit your manuscripts at

http://www.hindawi.com
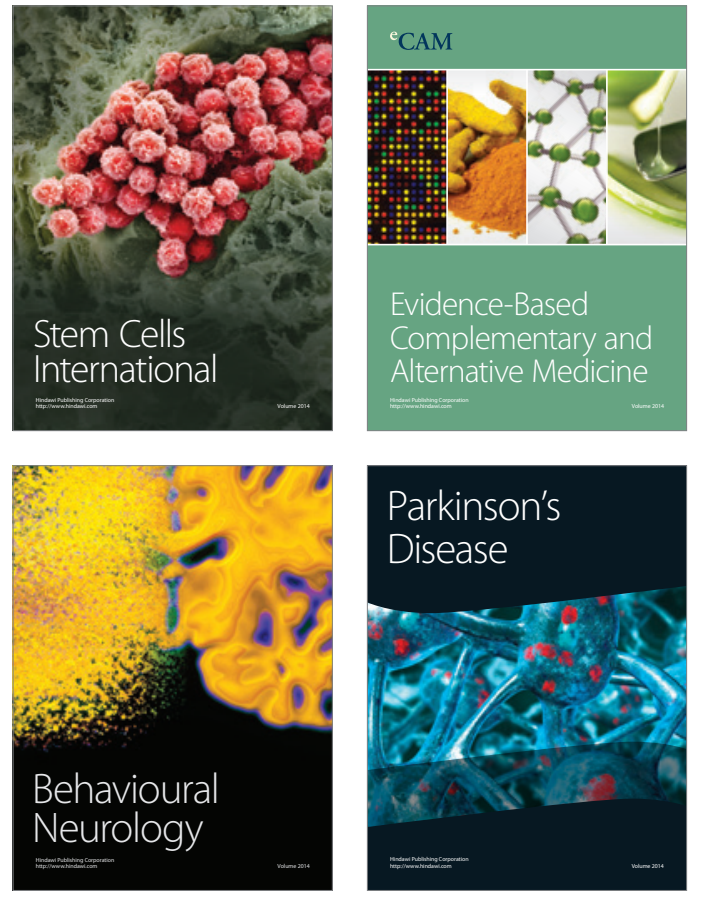
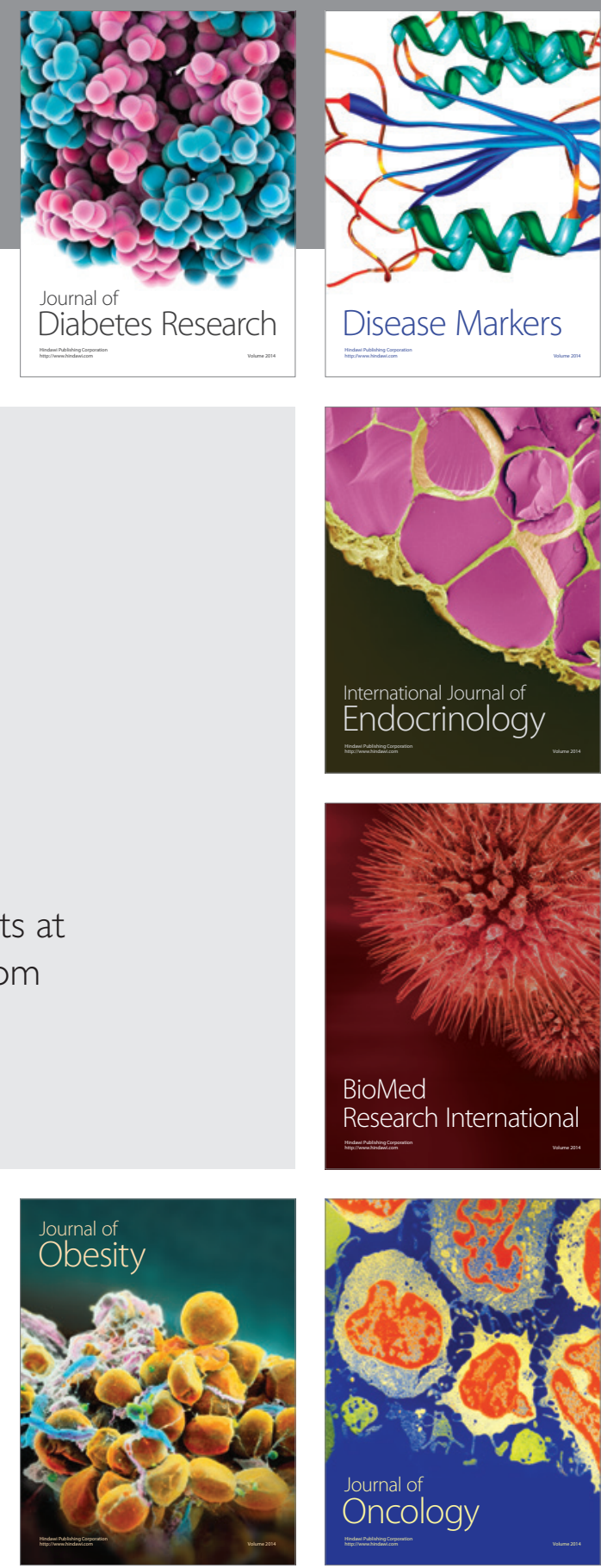

Disease Markers
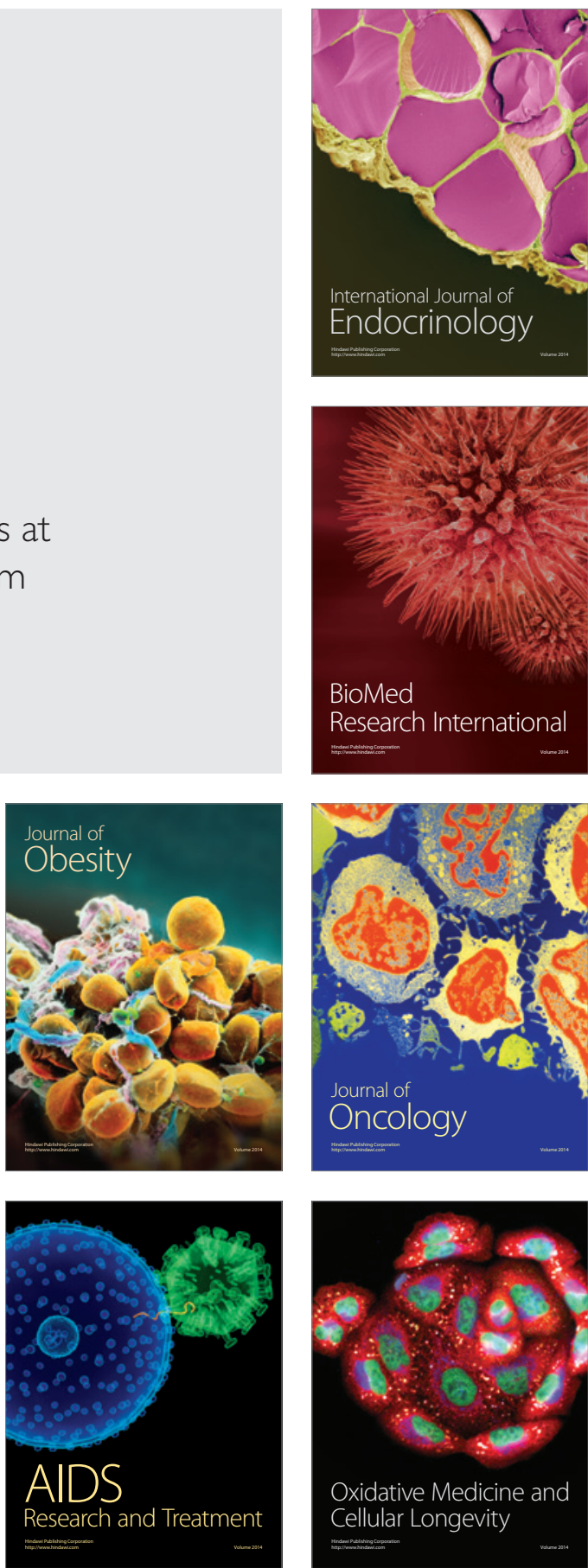